\title{
Analysis of Legal Change for Women Traveling without Mahram: A Case Study of the Kingdom of Saudi Arabia Royal Decree No.M/134 of 2019
}

\author{
Firqah Annajiyah Mansyuroh \\ Fakultas Syariah, UIN Antasari Banjarmasin, Jl. A. Yani No.KM.4, RW.5, Kebun \\ Bunga, Kec. Banjarmasin Tim., Kota Banjarmasin, Kalimantan Selatan 70235 \\ Email: firqahannajiyahmansyuroh@gmail.com
}

Article history: Received: 5 October 2018, Accepted: 12 February 2019, Published: 14 Desember 2019

\begin{abstract}
:
This paper departed from the problem on why the government of Saudi Arabia changed its policy on women's rights in the public sphere through Royal Decree No. M/134 of 2019. It revoked the ban on women for traveling without male relatives (mahram). This is literally surprising because Saudi Arabia is famous of its prohibition for women to travel without mahram due to its patriarchal culture with the rigid division of roles between women and men. The phenomenon requires a comprehensive explanation on the reasons behind the Saudi government's decision in the current situation. This research explored the factors beyond the decision using feminism approach and analyzes the relationship between social change theory and legal reform. It found that the main factor of women's freedom to travel without mahram is undeniably driven by the influence of economic and social changes. Moreover, Saudi is very passionate to achieve their 2030 vision.
\end{abstract}

\section{Keywords:}

Gender Equality; Change of Law; Vision 2030; Royal Decree

Author correspondence email: firqahannajiyahmansyuroh@gmail.com Available online at: http://ejournal.iainmadura.ac.id/index.php/alihkam/ Copyright (c) 2019 by al-ihkam. All Right Reserved 
Firqah Annajiyah Mansyuroh

\begin{abstract}
Abstrak:
Tulisan ini berangkat dari masalah mengapa pemerintah Arab Saudi mengubah kebijakannya tentang hak perempuan di ranah publik dengan menggunakan studi kasus Dekrit Kerajaan No. M/134 Tahun 2019 tentang pencabutan larangan perempuan bepergian tanpa mahram. Hal ini menjadi menarik karena Arab Saudi merupakan negara yang terkenal tidak memperbolehkan perempuannya bepergian tanpa kerabat lakilakinya. Hal ini disebabkan oleh kondisi sosial masyarakat Arab Saudi sangat erat dengan budaya Patriarki yang mengonstruksi pemikiran tentang pembagian peran antara perempuan dan laki-laki. Melihat fakta demikian, diperlukan penjelasan secara menyeluruh untuk menjelaskan alasan di balik keputusan pemerintah Saudi dalam situasi saat ini. Penelitian ini menelusuri faktor-faktor yang menodong keputusan tersebut dibuat dengan menggunakan pendekatan feminism dan menganalisis hubungan teori perubahan sosial dengan pembaruan hukum. Faktor utama kebebasan perempuan bepergian tanpa mahram tidak dipungkiri didorong oleh pengaruh perubahan ekonomi dan sosial. Ini dikarenakan Saudi menginginkan Visi 2030 mereka tercapai.
\end{abstract}

\title{
Kata Kunci:
}

Persamaan Gender; Pembaruan Hukum; Vision 2030; Dekrit Kerajaan

\section{Introduction}

The issue of women's rights is one of the hottest debate topics in Saudi Arabia. It leads to a variey of interpretation from Saudi Arabia religios scholars. In fact, almost all of Saudi women's rights were disadvantaged due to oppression rules formulated by both local religious figures and the government. However, they preferred to keep silent and simply accepted the reality as it was considering that what they experienced was a consuequence of what they believe. ${ }^{1}$

Nevertheless, the recent efforts of Saudi Arabian government in the context of women have been somewhat loosen of. They begin to sympathize on women who had long been restricted by a variety of

1Anis Rosida, “Wacana Modernisasi dalam Tantangan Peradaban, Peran Perempuan Sebagai Tonggak Sejarah Arab Saudi," Palita: Journal of Social-Religion Research 3, no. 1 (2018): 81-96, https://doi.org/10.24256/pal.v3i1.195.. 82. 
prohibition to access public sphere. This is clear, for example, from the lifting of a ban on driving for Saudi Arabian women by King Salman bin Abdul Aziz on September 26, 2017. The inauguration of this resolution really helped to resolve one of the old social dilemmas which became a big barrier for Saudi women to travel more freely outside the house. Therefore, most Saudi women consider the 2017 lifting as a symbolic victory over their hard work campaign since before the reign of King Salman bin Abdul Azis. ${ }^{2}$

After the 2017 lifting, Arabian Peninsula reexperienced another shocking yet interesting phenomenon by the issuence of a policy which opens women's access to several public roles. This occured at the same time when Saudi Arabia still refuses to implement a democratic system and maintain the kingdom in its monarchic system. The policy was then supported by the Saudi government's decision through King Salman bin Abdul Aziz Saud's issuencce of Royal Decree No. M / 134 dated 30 July 2019 amending the Royal Decree M / 24 of 28 August 2000. The amandment on the passport allows Saudi women to travel abroad without male guardians (later referred as mahram). It also enables them to get passports without the mahram's consent. ${ }^{3}$

The decision is quite surprising to many parties, ranging from those who live within the territory of Saudi Arabia to international citizens. This is particularly because Saudi Arabia always gets the public eye for the treatment of its female citizens. Recently, the highlighted issue of Saudi Arabian women is mostly about some Saudi women who seek asylum abroad. ${ }^{4}$ It was very much due to the recent royal decree published in the official royal weekly newspaper Umm al-Quran on Friday which stipulated that a Saudi passport must be issued to every citizen who applies for it while those over the age of 21 do not need any permission for traveling. ${ }^{5}$

\footnotetext{
${ }^{2}$ Nimas Ayu Mujihastuti, “Analisis Perubahan Kebijakan Arab Saudi tentang Peran Perempuan di Ranah Publik: Studi Kasus Royal Decree No. M/85 Tahun 2017" (Universitas Airlangga, 2019), https://doi.org/10.1051/matecconf/201712107005. 2.

سلما بن عبد العزيز آل سعود, “"مرسوم ملكي رقم (م/134) وتاريخ 1440-11-27هـ," 29/11/1440 العدد 4790, 3 الصفحة 14, https:/ / perma.cc/9PHW-EG7D.

4BBC, "Saudi Arabia Allows Women to Travel Independently," bbc news, 2019, https://www.bbc.com/news/world-middle-east-49201019.

سعود, “"مرسوم ملكي رقم (م/134) وتاريخ 1440-11-27هـ."
} 
The root of the old prohibition lied in the royal insistence on gender segregation between women and men in addition to Islamic traditions about restriction for women to go traveling except with their husband or mahram. The Interpretation of this Islamic value later became a guideline for the legal system in Saudi Arabia and therefore limited women's activities in the public sphere. This inevitably impacted on various aspects of daily life. However, later on, in the midst of an oppressive situation under the valid laws and norms, fundamental and unsual changes occured in a patriarchal environment such as Saudi Arabia. For this reason, I think it is a big need to find out the driving factors beyond the emergence of changes in royal decree which then led to the lifting of ban on traveling without mahram for Saudi Arabia women.

\section{Research methods}

This study uses a qualitative approach to examine influencing factors on the changes in the Royal Decree of Saudi Arabia. Futhermore, it explores the factors using a feminism approach to the issue of women's rights and analyzes the relationship of theories on the influence of social change with the reform of Islamic law.

\section{Saudi Women and Traveling Without Mahram}

Since its establishment as a kingdom, Saudi has been a constitutional kingdom which regulated the prohibition for women to travel without mahram. This prohibition was also based on the jurists' decision regarding a hadith on the prohibition of women's traveling without mahram. It made very much sense, therefore, for Saudi Arabia as an Islamic law based country to prohibit women's abroad travel and own a passport. Under this policy, especially at the beginning of its establishment, Saudi kingdom was famous as the very conservative and fundamental ones in religious school. ${ }^{6}$ follows:

Among the hadith texts about traveling with mahram is as

${ }^{6}$ Fatkhur Roji, “Kebijakan Ruang Publik Perempuan: Agenda Politik Double Interest Saudi," International Journal Ihya' 'Ulum Al-Din 19, no. 2 (2017): 271-84, https://doi.org/10.21580/ihya.18.1.1740., 276. 


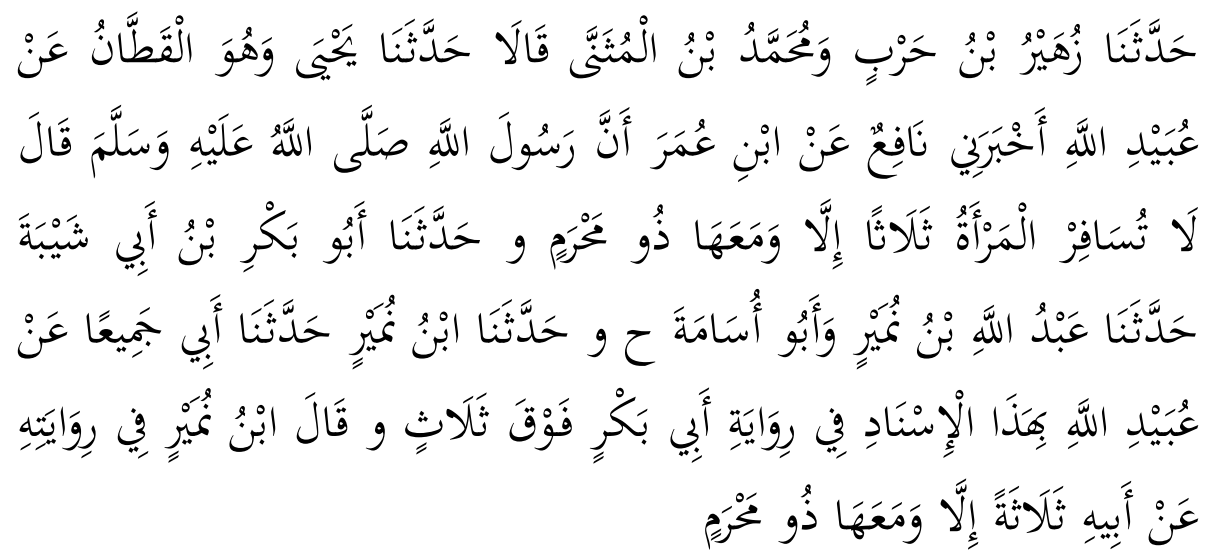

"Had told us [Zuhayr bin Harb] and [Muhammad bin al-Mutsanna] both said, had told us [Yahya al-Qaththan] from ['Ubayd Allah] had told me [Nafi'] from [Ibn 'Umar] that the Messenger of Allah sallallaahu' alayh wa sallam said: "A woman cannot travel for three days unless accompanied by her mahram." And had told us [Abu Bakr ibn Abu Shafi'ah] have told us ['Abd Allah bin Numayr] and [Abu Usamah] -in other narrations- and had told us [Ibn Numayr] had told us [my father] of ['Ubayd Allah] with this isnad. And in his history, Abu Bakr is listed; "In the top three (days)." And he also said in his history, from his father; "Except when she is with her mahram."7

Specifically, there found no explanation on the causes or motives behind the emergence of this hadith or so called asbāb wurüd. However, according to Imam Badr Al-Dīn Abi Muhammad Mahnūud Ibn Ahmad al-'Ainī, this hadith occured when the wives of prophet's companions wanted to perform the hajj while their husband were still

${ }^{7}$ Muslim bin al Hajjaj bin Muslim bin Kausyaz al-Qusyayrī al-Naysaburī, Shahih Muslim (Dar Al Mughni, 1998). Hadith number 2381-2391. Muhammad bin Ismā'īl alBukhārī, Shahīh al-Bukhāri (Beirut: Dar Ibn Katsir, n.d.). Hadith number 1024, 1025, 1122, 1729, 1731, and 1858. Muhammad bin 'Isa al-Tirmidzī, Sunan al-Tirmidzī (Riyadh: Maktabatu Al Ma'arif, n.d.). Hadith number 1089 and 1090. Abū Dāwud Sulaymān bin al-Asy'atsī Al-Sijistānī, Sunan Abū Dāwud (Makkah: International Ideas Home, 1999). Hadith number 1465, 1466, and 1467. Muhammad bin Yazīd Abū `Abd Allah, Sunan Ibnu Mājah Vol 1 (Beirut: Dar Al-Fikr, n.d.). Hadith number 2889. Abū

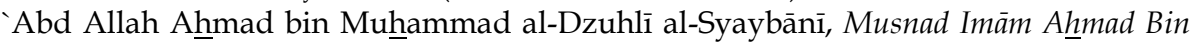
Hanbal (Beirut: Muassasah al-Risālah, 1995). Hadith number 1153, 1934, 4614, 4696, 6289, 6290, 11054, 11501. Mālik bin Anas, Al-Muwaththā' (Libanon: Dar Al-Ma'rifah, 2003). Hadith number 2973. 'Abd Allah bin 'Abd al-Rahman al-Darimī, Sunan alDarimī (Riyādh: Daarul Mughni, n.d.). Hadith number 2678 
at the battlefield. In line with it, Ibn Hazm also ensured that the context of this hadith was a war situation and therefore women needed accompanion from their husbands or mahram to go traveling. ${ }^{8}$

The above mentioned hadith can be viewed through, at least, two types of approach, namely textual and contextual understanding. The former shows that women are totally not allowed to leave the house without mahram accompaniment. Based on this approach, many scholars deliver opinions that women should not leave the house, even for hajj except with their mahram along with. ${ }^{9}$

However, the later approach takes the rationes legis values from the prohibition as an effort to understand the historical context. They consist of security and modesty. This drives to the the current contextualization which considers security and modesty of women's traveling without mahram are what really matter. Consequently, if the security is well guaranteed and women are culturally appropriate to travel by themselves, it would not be a problem. ${ }^{10}$

Under the power of the al-Saud regime since 1932 until the middle of 2019, the legitimacy of the Saudi Arabian monarchical power regarding prohibition on women's traveling without mahram was still in force. This combination of governmental interference and cultural elements significantly caused imbalanced power between Saudi Arabian men and women in various life aspects. For instance, women were limited to access the justice system so that any judicial matters they dealt with were entrusted to their male relatives as

${ }^{8}$ Ahmad Fawaid, "Reinterpretasi Hadith tentang Mahram (Pendekatan Hermeneutika)," Nur El-Islam 3, no. 1 (2016): 176-95., 189.

${ }^{9}$ Atiyatul Ulya, "Konsep Mahram Jaminan Keamanan atau Pengekangan Perempuan," Al-Fikr 17, no. 1 (2013): 245-55., 251. Imam Ibnu Hajar, "Reinterpretasi Hukum Larangan Bepergian tanpa Mahram Bagi Perempuan," Al-Manahij Jurnal Kajian Hukum Islam VI, no. 1 (2012): 143-56. Maulidah Tri Utami, "Mahram Implications in Women's Travel," Jurnal Hunafa: Studia Islamika 16, no. 1 (2019): 88110, https:// doi.org/10.1017/CBO9781107415324.004.

${ }^{10}$ Ghufron Hamzah, "Reinterpretasi Hadith Larangan Melukis dan Larangan Perempuan Bepergian tanpa Mahram (Hermeneutika Fazlur Rahman)," Jurnal Iqtisad: Reconstruction of Justice and Welfare for Indonesia 6, no. 1 (2019): 73-92., 89. Holilur Rohman, "Reinterpretasi Konsep Mahram dalam Perjalanan Perempuan Pespektif Hermeneutika Fazlur Rahman," Al-Hukama 07, no. 02 (2017): 502-25. Ghufron Hamzah, "Reinterpretasi Hadith Larangan Perempuan Bepergian tanpa Mahram dan Larangan Melukis (Pendekatan Sosio-Historis Dan Antropologis)," The Journal for Aswaja Studies 1, no. 1 (2019): 23-33. 
representatives. Another case was in education field in which women could not freely express their own opinion as a part of their human right. This limited acces inevitably impacted on what they wanted to do. ${ }^{11}$

Many cases showed that most of Saudi women who wished to continue their studies based on their interests and talents needed to go to universities abroad. In fact, its is a basic right for every individual to study depending on what they wish to take. However, the facts in Saudi Arabia showed that access to education was still based on gender segregation. This certainly restricted women's freedom in making choices for their own future. ${ }^{12}$ The condition was unfortunately aggravated by the government regulations on the prohibition for their traveling without mahram. Before the ban was amended last 2019, Saudi women who wanted to travel must get accompanied by their mahram ranging from father, brother, grandfather, son, husband to uncle.

Before the amandment, this ultra-conservative country considered women traveling without mahram as a taboo. The assumption was based on the absurd belief that the activity is a symbol of promiscuity which spreads the sin to surrounding. Another assumption was the big possibility for women to put off the veil they wore when traveling alone. In addition to these two reasons, some men in Saudi Arabia still believed that allowing women to travel alone will lead to the traditional values reduction particularly on gender segregation. ${ }^{13}$

The existence of such rules and norms was a real indicator of putting women in a less important position than those of men. The prohibition on women's traveling associated with obligation to maintain their honor was actually an effort to put them as the main regulator of the family. This will then avoid them to build a good career and earn their own living. Another example was the regulation on the guardian's qualification which is exclusive for sons. Women,

\footnotetext{
11Rosida, "Wacana Modernisasi dalam Tantangan Peradaban, Peran Perempuan sebagai Tonggak Sejarah Arab Saudi.", 91.

${ }^{12}$ Mujihastuti, "Analisis Perubahan Kebijakan Arab Saudi tentang Peran Perempuan di Ranah Publik: Studi Kasus Royal Decree No. M/85 Tahun 2017.”, 4.

13Ibid., 5.
} 
therefore, were only considered as contributors without any authority in a Saudi family. ${ }^{14}$

However, eventually, in the mid of last 2019, Saudi Arabia issued a Royal Decree No. M/134 amending Royal Decree No. M/24 dated August 28, 2000 regarding passport and therefore allows Saudi women to travel abroad without mahram. The amendment also enables Saudi them to get passport without the mahram's consent. Previously, article 2 of the Royal Decree No. M/24 instructed that passports can only be given to Saudi men while the amended Article 2 changes it into "a passport can be given to anyone with Saudi citizenship."

The new amendment also revoked article 3 of Royal Decree No. M/24 which required Saudi men to mention their wives, unmarried daughters, and young sons in their passports. The next article, namely article 4 Royal Decree No. M/24, instructed that a separate passport can be issued to those in guardianship. The amanded version, article 4 of the Royal Decree No. M / 134, meanwhile, meanwhile, stated that passports can be issued to those in guardianship and the orphans." 15

In addition to those mentioned, other amendments were reported to have been ratified targeting the Royal Decree No. M/7 December 12, 1986 regarding the civil status. This aims to improve women's legal status as clear from the amanded article 30 of the Royal Decree No. M/7 enabling a Saudi woman resident to mention her name at the home address instead of their hubands' names. Likewise, article 33 amended from the same decree now allows women to report the birth of their newborn to the authorities for the birth certificates. Previously, only the newborn's father or closest male relatives aged 18 years old at minimum who could report a birth for getting the birth certificate. ${ }^{16}$

${ }^{14}$ Gita Murniasih, Diah Handayani, and Taufik Alamin, "Proses Domestifikasi Perempuan dalam Budaya Arab (Analisis Framing Model Zhongdang Pan san Gerald M. Kosicki Dalam Film Wadjda)," Mediakita 2, no. 1 (2018): 1-16., 13.

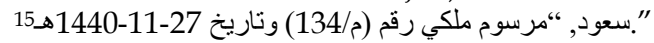

16"Saudi Arabia: Law on Passports Amended to Allow Women to Travel Abroad Without a Male Guardian | Global Legal Monitor," accessed December 10, 2019, http:/ / www.loc.gov/law/foreign-news/article/saudi-arabia-law-on-passportsamended-to-allow-women-to-travel-abroad-without-a-male-guardian/. 
Despite the recent reforms, other parts of the guardianship system still exist. This includes obligation for women to get permission from their mahram before getting marriage, living alone, or leaving the prison after the arrest period. Women, furthermoe, still cannot legally inherite citizenship and give consent for their children to get married. ${ }^{17}$

Relating to this issue, Sebastian Usher, a BBC Arab affairs analyst, said that the decree was already the biggest step so far to dismantle the male guardianship system in Saudi Arabia. This potentially has a close relation with Saudi women's rights activists' long time struggle to remove restrictions on their lives, including their petition to the authorities demanding the changes 18 just after the first elections for women were held in last December 2015.19

Many Saudi women celebrated the joy of this decree by reporting it to the world through Twitter. One of wich was the leading influencer and talk show host Muna Abu Sulayman who wrote: "A generation growing up completely free and equal to their brothers." 20 Before, Muna vigorously criticized this ban as clear from her popular statement as follows:

"Maybe, the cancellation of some woman's dreams due to the travel barrier is a small disturbance for most people. However, it is actually a symbolic insult to broader concept of adult and accountability as well as the meaning of character". ${ }^{21}$

In line with Muna, the first royal diplomat woman serving as Saudi ambassador to America, Princess Reema bint Bandar Al-Saud, was also happy with this change by saying:

17“'Saudi Arabia: Law on Passports Amended to Allow Women to Travel Abroad Without a Male Guardian | Global Legal Monitor."

18BBC, "Saudi Arabia Allows Women to Travel Independently."

${ }^{19}$ Cammelianne Typhano Rachmadie and Suryo Ediyono, "Reformasi Sistem Kebudayaan Di Arab Saudi Masa Pemerintahan Raja Abdullah (2005- 2015)," Millati: Journal of Islamic Studies and Humanities 2, no. 1 (2017): 41-64, https://doi.org/10.18326/millati.v2i1.41-64., 53.

20"Muna Abu Sulayman منى (@abusulayman) on Twitter,” accessed December 11, 2019, https:/ / twitter.com/abusulayman.

21"Saudi Arabia Extends New Rights to Women in Blow to Oppressive System - The New York Times," ${ }^{\prime}$ accessed December 11, 2019, https://www.nytimes.com/2019/08/02/world/middleeast/saudi-arabiaguardianship.html. 
"I am elated to confirm that KSA will be enacting amendments to its labor and civil laws that are designed to elevate the status of Saudi women within our society, including granting them the right to apply for passports and travel independently." 22

Responding the situation, women activists praised the guardianship law changes but still demanded further policies. They demand the kingdom to allow Saudi women to marry themselves, live alone and get out from state facilities, such as shelters of domestic violence, without the consent of their mahram. ${ }^{23}$

However, other certain parties feel that they must be alert for the new reforms. Some conservatives in the country reacted negatively to these changes and told Reuters International news agency as follows "Imagine if your daughter grows up and leaves you and doesn't return. Are you happy?" 24 They are so afraid that women's freedom to travel abroad alone may lead them to build a career and settle down far away without returning to Saudi Arabia.

\section{Analysis of Legal Changes in Saudi Women Traveling Without Mahram}

The economic and social reform policies of Muhammad bin Salman inevitably affect on the position of conservative Saudi scholars. The most possible alternative to take is transforming into a more moderate way. ${ }^{25}$ Moreover, most of those scholars have now been silenced while some of their old teachings are removed from official government's websites. Other parties who tend to oppose

\footnotetext{
22" Reema Bandar al-Saud on Twitter: 'I Am Elated to Confirm That KSA Will Be Enacting Amendments to Its Labor and Civil Laws That Are Designed to Elevate the Status of Saudi Women within Our Society, Including Granting Them the Right to Apply for Passports and Travel Independently. 1/4,'" accessed December 11, 2019, https:/ / twitter.com/rbalsaud/status/1157110654089777153.

${ }^{23}$ "Saudi Arabia Extends New Rights to Women in Blow to Oppressive System - The New York Times."

24BBC, "Saudi Arabia Allows Women to Travel Independently."

${ }^{25}$ Mahmud Hibatul Wafi, "Diskursus Reformasi Arab Saudi: Kontestasi Kerajaan Saudi Dan Wahabi," Journal of Islamic World and Politics 2, no. 1 (2018): 228-39, https://doi.org/10.18196/jiwp.2113., 237.
} 
Mohammed's social reforms remain silent either because of their respect on the monarchy or fear of being arrested for speaking out. ${ }^{26}$

For decades, Saudi scholars have promoted the strict separation between women and men while preaching that it is better for women to stay at home. The internalization of fitnah (slander), khalwah (being in a lonely place with another sex), and mahram concepts is so strong in Saudi Salafi religious thought. Consequently, a woman was prohibited from traveling on a plane even if her relatives can take her to the airport and then other relatives will pick her up at the destination airport. This prohibiting fatwa of traveling was literally issued by Ibn Utsaimin citing the concept of fitnah, khalwah and mahram.27

In this case, a contemporary Islamic law scholar, Al-Qaradawi, mentioned that the law will continue to experience any renewal and reform. It is its nature to keep changing and even probably returning to the first origin as the time goes by. Therefore, the legal thought also needs renewal and reformulation along with the emergence of new social needs for fatwa and new legal considerations even though the legal text does not change. Since long time ago, the figh scholars had proposed that the law will apply along with its 'illat (al- $\underline{h u k m}$ yadur $m a^{\prime} a$ 'illatih). ${ }^{28}$

Based on this, al-Qaradhāwī thought that women may travel without mahram with logical reasoning, such as when safety aspect as the factor beyond the prohibition at the hadith is well assured. At the time when the hadith was spoken, the journey was commonly carried on camels, donkeys, or horses passing through barren deserts which were full of dangers and threats, such as wild animals, robbers, thieves and desert bandits. Meanwhile nowadays, traveling is so fast and safe that it raises women's self-confidence and eliminates concerns about their safety. Furthermore, al-Qaradhāwī supported his argument by mentioning the fact that Aisha, the wife of prophet, was

\footnotetext{
${ }^{26 " S a u d i ~ A r a b i a ~ E x t e n d s ~ N e w ~ R i g h t s ~ t o ~ W o m e n ~ i n ~ B l o w ~ t o ~ O p p r e s s i v e ~ S y s t e m ~-~ T h e ~}$ New York Times."

27Faqihuddin Abdul Kodir, "Metode Interpretasi Teks-Teks Agama dalam Mazhab Salafi Saudi Mengenai Isu-Isu Gender," Holistik 13, no. 02 (2012): 137-65., 158.

${ }^{28}$ Badri Khaeruman, "Al-Qaradawi Dan Orientasi Pemikiran Hukum Islam Untuk Menjawab Tuntutan Perubahan Sosial," Wawasan: Jurnal Ilmiah Agama Dan Sosial Budaya 1, no. 2 (2016): 227-38, https://doi.org/10.15575/jw.v1i2.740., 237.
} 
permitted by 'Umar to go on the pilgrimage accompanied by Usman and 'Abd al-Rahman bin 'Auf and there found no other companion who denied 'Umar's decision. ${ }^{29}$

This discussion shows that different perspectives on a specific concept in Islam have come to the gender issues and some parties still consider it as a taboo. ${ }^{30}$ In fact, women's friendly law reform is a conscious, planned and sustainable determination in the framework of a legal system both in substantive and legal institutions. Certainly, it needs to approach the law from various life aspects so that it becomes visionary and operating as a responsive legal norm. As a consequence, the law will always go through evolutionary and revolutionary changes. 31

It is worth for reconsideration, therefore, when a specific law is highly irrelevant such as the prohibition for women to access public areas, including work place, for the sake of avoiding the fitnah. The necessity of accompaniment either from mahram or husband for them to travel is also too difficult to apply in the current era because human needs are very complex. There must be a lot of wasted time, money and energy if every step of women needs such accompaniment. Moreover, the qualified men for the accompaniment who are supposed to be able to cope with any barrier and secure women from any trouble probably become the objects of any crime or other unexpected condition. This means that there is no guarantee that men will be able to maintain the safety of the women they watch over. ${ }^{32}$

On a certain specific case, it becomes unfair to blame women who "wander alone" for adultery or rape cases while ignoring involved men who can't control their desire in the public sphere. Thus, convicting haram and immoral for women's journey without mahram accompaniment does not solve the problem. Instead, it

${ }^{29}$ Badri Khaeruman, Hukum Islam dalam Perubahan Sosial (Bandung: Pustaka Setia, 2010)., 178-181.

${ }^{30}$ Nalom Kurniawan, "Hak Asasi Perempuan dalam Perspektif Hukum Dan Agama," Jurnal Konstitusi 4, no. 1 (2011): 153-74., 154.

31Zainal Arifin Hoesein, "Pembentukan Hukum dalam Perspektif Pembaruan Hukum (Law Making on the Perspective of Legal Reformation)," Jurnal Rechtsvinding: Media Pembinaan Hukum Nasional 1, no. 3 (2012): 307-27., 318.

32Zulfatun Ni'mah, "Fiqih Perubahan Untuk Perempuan (Upaya Menjawab Keusangan Dan Kekosongan Hukum Bagi Perempuan)," MUWAZAH 1, no. 1 (2009): 41-48., 46. 
tarnishes the nature of humans to work and betrays the religious orders to seek knowledge (al-'ilm). ${ }^{33}$

Based on this, the renewal of Islamic legal thought becomes an inseparable part of the changing life process of a society. On the other hand, social changes from the classical period to the contemporary ones certainly require the changes in law. The social dynamics and Islamic law are interrelated in the making the changes. ${ }^{34}$

Related to this, al-Marāghī in his Qur'anic interpretation mentioned that the laws enactment is due to the human's interest, while the interests can be diverse depending on the different time and place. Therefore, if a law was promulgated at the specific time due to a certain need, it will be wise to replace it with more suitable one when the old need had gone or changed so that the 'newer' law can fit into the current condition. 35

The winds of change for equality between women and men continue to blow in Saudi Arabia. Nowadays, women can even pursue careers as pilots and cabin crews. Saudi Arabia reforms itself to be modern and open. Regarding to this change, the Saudi wrote in their 2030 Vision that Islam is the main thing and remains the foundation of the way of life of both citizens and country. Additionally, Islam is the basic of all laws, decisions, actions and objectives of Saudi Arabia. However, it does not refer to conservative Islam anymore, but the moderate ones. It means the Islamic guidelines on the values of hard work, dedication, superority, the principles and values of moderation, tolerance, discipline, equality, and transparency as the whole values expected to be the cornerstones of the country's success. ${ }^{36}$

In connection to the drastic changes occuring in Saudi Arabia in the past four years, the name of Prince Mohammed bin Salman is often touted as a very important and influential figure. After being officially inaugurated as the Crown Prince, Mohammed bin Salman

\footnotetext{
${ }^{33} \mathrm{Ni}^{\prime} \mathrm{mah}, 46$.

${ }^{34}$ Fathurrahman Azhari, "Dinamika Perubahan Sosial Dan Hukum Islam," Al-Tahrir: Jurnal Pemikiran Islam 16, No. 1 (2016): 197-221, https://doi.org/10.21154/altahrir.v16i1.322., 218.

${ }^{35}$ Ahmad Mushthafa al-Marāghī, Tafsìr al-Marāghī Vol 1 (Mesir: Mustafa Al-Babi AlHalibi, n.d.)., 187.

36KSA, “Vision 2030 Kingdom of Saudi Arabia," 2016, 1-85., 16.
} 
published Vision 2030 as a goal or objectives that Saudi Arabia government wants to achieve. There are three main pillars of the Vision 2030. First is making Saudi Arabia as the center of all Arabs and other Islamic countries. Second is making Saudi Arabia a global investment/investor center. Third is optimizing the trade through geographical position among three continents (Asia, Europe and Africa). ${ }^{37}$

In an effort to transform into a more open country, Crown Prince Mohammed bin Salman also launched a plan in 2016 to change the economy in 2030. It aims to reduce the unemployment rate from $11.6 \%$ to $7 \%$ and increase women's participation in the workforce to $30 \%$ from 22\%. ${ }^{38}$ Eqbal Darandari, a female member of the Shura Council who had long campaigned to revoke the prohibition for women's travel without mahram really supports the Royal Decree No. $\mathrm{M} / 134$. She stated that the step is at the very right direction and is certainly in line with the September 2017 decision that gave women the right to drive. ${ }^{39}$

Enforcement of any country's policy will be certainly inseparable from the ruler's strategy in reaching the country's goal. ${ }^{40}$ In this context, the royal political policy is a special agenda in influencing and facilitaing the birth of a certain policy. Meanwhile, the merge between the law and social change will lead into one of two functions. First, it can function as social control when the law serves as a means to maintain social stability. Second, it can also function as a means to change society or so called social engineering. In this case, the law is put as a means to modify social structure. This happens when social change comes lately than the legal change and will then bring society into a new order. ${ }^{41}$

Although this rule may seem minor, the impact can be quite extensive both in social and economic terms. In social perspective, for

\footnotetext{
${ }^{37}$ Ibid.

${ }^{38}$ Ibid., 39.

39"Saudi Arabia: Law on Passports Amended to Allow Women to Travel Abroad Without a Male Guardian | Global Legal Monitor."

40Roji, "Kebijakan Ruang Publik Perempuan: Agenda Politik Double Interest Saudi.", 277.

${ }^{41}$ Gibtiah and Yusida Fitriati, "Perubahan Sosial Dan Pembaruan Hukum Islam Perspektif Sadd Al-Dzari'ah," NURANI 15, No. 2 (2015): 101-14., 109.
} 
example, Saudi career women found their mobility becomes more complicated. Inevitably, every working day, they needed to provide special fees for accommodation to and from workplace especially if their mahram is unable to deliver them and pick them up. In addition to impaired mobility, Saudi women had a high degree of independence to their mahram. In other words, they couldn't enjoy any individual freedom. Meanwhile in terms of economy, the old regulation required much more costs for daily accommodation which also affected the unemployment rate and the economy of country. It becomes much clearer that gender segregation plays its role in the field of employment and the country's economy. This is also one of the main reasons why the number of career women in Saudi Arabia was still low. 42

In addition to Vision 2030 and economic reasons, political observers have argued that Saudi Arabia's Decree No. M / 134 in 2019 also 'fixes' the image of the Saudi in the international level. This particularly relates to the some cases of Saudi prominent women activists who involved in women's rights campaigns yet was detained or had been abroad. Internationally, their efforts have received great attention. For many Saudis, both men and women, this situation makes the Crown Prince a hero. Outside the Kingdom, it alsohelps to renew the country's image after the issue of Jamal Khashoggi's murder, many arrested women, and those who sought asylum abroad. However, both Saudi Arabia hardliner conservatives and women's rights activists still have their suspicions on Mohammed bin Salman's motives on the changes. They assumed that it was all about the real proof of the continuous accumulation of his power in political, financial or cultural aspect. ${ }^{43}$

In his research, Roji, for example, concluded that the recent Saudi's government policy was actually a double interest politic. They are none other than to save the Saudi royal government itself in the midst of abundant oil wealth and various stringent economic contests. The Saudi government, according to him, will no longer rely on those mentioned because they can get economic input from a variety of

\footnotetext{
${ }^{42}$ Mujihastuti, "Analisis Perubahan Kebijakan Arab Saudi tentang Peran Perempuan di Ranah Publik: Studi Kasus Royal Decree No. M/85 Tahun 2017.", 5.

${ }^{43 B B C}$, "Saudi Arabia Allows Women to Travel Independently."
} 
incomes, such as fuel tariffs, taxation rates and licensing rates issued by the kingdom. Other possible advantages are to maintain royal security both by diverting issues and planning a diplomatic stategy for international relations to strengthen the kingdom's resilience from various possible conflicts. ${ }^{44}$

On the other hand, a dissertation about changes in Saudi Arabian policy towards women mentioned about the leading international and non-international factors. It further assumed that the government's decision to change their policy was indeed due to the following factors: a) the pressure within Saudi Arabia itself, particularly Saudi women's activist agencies; b) the active participation of women parliamentary members in the process of policy making recommendations; c) the role of the new Crown Prince of Saudi Arabia, Mohammed bin Salman; and d) international condemnation of the Saudi government. ${ }^{45}$

Above all, this case clearly shows that the gender politics have really changed. Although it ran slowly, a sudden turnaround unpredictably occurs in Saudi Arabia. These all imply that the change is mostly a matter of time.46 It began from the appointment of a woman Minister and Women's Shura Council, the organization of women's elections, women's legal access to stadiums, cinemas, music shows, car driving, to the most recent, namely traveling without mahram. It becomes so much obvious that the Saudi government has strong willingness to increase women's participation in civil society and support all types of organizations campaigning women's rights. Furthermore, these also imply a big expectation for women to drive the economic and religious narration as two most prominent leading factors for the advancement of both Saudi Arabia and Islam.

Moreover, various researches from the World Bank and other economic studies conducted in Bangladesh, Brazil, Canada, Ethiopia

\footnotetext{
${ }^{44}$ Roji, “Kebijakan Ruang Publik Perempuan: Agenda Politik Double Interest Saudi.”., 281.

${ }^{45}$ Mujihastuti, "Analisis Perubahan Kebijakan Arab Saudi tentang Peran Perempuan di Ranah Publik: Studi Kasus Royal Decree No. M/85 Tahun 2017.”, 9.

46Siti Rohmah Soekarba, "Determinants of Patriarchy in the Middle East: Hope for the 2030 Vision in a New Saudi Arabia," in 2nd International Conference on Strategic and Global Studies (ICSGS 2018), vol. 365 (Atlantis Press: Advances in Social Science, Education and Humanities Research, 2019), 193-200., 199.
} 
and the United Kingdom have strengthened the assumption about women's participation. Involving women in a country's economic activities is believed to give significantly positive effect because they will likely spend their income to increase family welfare such as for nutrition, health and education. Societies with greater gender equality which, among others, allow women to work in public sphere, tend to grow faster and more evenly. Lots of evidence have also showed that programs on poverty reduction, environmental sustainability, customers' choice, and decision-making on various beneficial and important topics for society can be fully succesful when the role of women can be equal to those of men. ${ }^{47}$

\section{Conclusion}

From the above explanation, it is clear that the social dynamics and Islamic law are interrelated in the changes occuring in Saudi Arabia. The changes in Islamic law can lead to social change as long as the Islamic law still becomes customary or positive law among society. Likewise, the social change also leads to the change of Islamic law. The emergence of of the Kingdom of Saudi Arabia Decree No. M/134 of 2019 concerning the freedom of women to travel without mahram was undeniably driven by the influence of economic and social change.

Enforcement of any country's policy, furthermore, will be inseparable from the ruler's strategy in reaching the country's goal. To examine the efforts of modernization, openness and moderate Islam in Saudi Arabia, one compatible issue to observe is on women and gender, particularly the old bad stigma of the country in treating its women citizens. Recently, Saudi government wishes that role of women will be worth as an influential agency to encourages social change in the existing structure.

\section{Bibliography}

Abu `Abd Allah, Muhammad bin Yazìd. Sunan Ibn Ma>jah. Beirut: $\mathrm{Da}>\mathrm{r}$ Al-Fikr, n.d.

Al-Darimī, `Abd Allah bin `Abd al-Rahman. Sunan al-Da>rimi $>$.

47Soekarba., 198. 
Riyadh: Da>rul Mughni, n.d.

Al-Marāghī, Ahmad Mushthafa. Tafsīr Al-Mara $>$ ghi>. Mesir: Mustafa Al-Babi Al-Halibi, n.d.

Al-Sijistānī, Abū Dāwud Sulaymān bin al-Asy'ātsī. Sunan Abu> $D a>u d$. Makkah: International Ideas Home, 1999.

Al-Naysabūrī, Muslim bin al- $\underline{\text { Hajjāj }}$ bin Muslim bin Kausyaz alQusyayrī. Sha>hih Muslim. Da>r Al Mughni, 1998.

Anas, Mālik bin. Al-Muwaththā'. Libanon: Da>r Al-Ma'rifah, 2003.

Al-Syaybānī, Abū 'Abd Allah Aḥmad bin Muhammad al-Dzuhlī. Musnad Imām Ahmad bin ㄴanbal. Beirut: Muassasa al-Risalah, 1995.

Al-Tirmidzī, Muhammad bin 'Isa. Sunan al-Tirmidzī. Riyadh: Maktabatu Al Ma'arif, n.d.

Azhari, Fathurrahman. "Dinamika Perubahan Sosial Dan Hukum Islam." Al-Tahrir: Jurnal Pemikiran Islam 16, no. 1, 2016. https://doi.org/10.21154/al-tahrir.v16i1.

BBC. "Saudi Arabia Allows Women to Travel Independently." bbc news, 2019. https://www.bbc.com/news/world-middle-east49201019.

Al-Bukhārī, Muhammad bin Ismā’̄̄l. Shahīh al-Bukhārī. Beirut: Dar Ibn Katsir, n.d.

Fawaid, Ahmad. "Reinterpretasi Hadith Tentang Mahram (Pendekatan Hermeneutika)." Nur El-Islam 3, no. 1, 2016.

Gibtiah, and Yusida Fitriati. "Perubahan Sosial Dan Pembaruan Hukum Islam Perspektif Sadd Al-Dzari'ah." NURANI 15, no. 2, 2015.

Hajar, Imam Ibnu. "Reinterpretasi Hukum Larangan Bepergian Tanpa Mahram Bagi Perempuan." Al-Manahij Jurnal Kajian Hukum Islam VI, no. 1, 2012.

Hamzah, Ghufron. "Reinterpretasi Hadith Larangan Melukis Dan Larangan Perempuan Bepergian Tanpa Mahram (Hermeneutika Fazlur Rahman)." Jurnal Iqtisad: Reconstruction of Justice and Welfare for Indonesia 6, no. 1, 2019.

- - - "Reinterpretasi Hadith Larangan Perempuan Bepergian Tanpa Mahram Dan Larangan Melukis (Pendekatan SosioHistoris Dan Antropologis)." The Journal for Aswaja Studies 1, no. $1,2019$.

Hibatul Wafi, Mahmud. “Diskursus Reformasi Arab Saudi: Kontestasi 
Kerajaan Saudi Dan Wahabi." Journal of Islamic World and Politics 2, no. 1, 2018. https:// doi.org/10.18196/jiwp.2113.

Hoesein, Zainal Arifin. "Pembentukan Hukum Dalam Perspektif Pembaruan Hukum (Law Making on the Perspective of Legal Reformation)." Jurnal Rechtsvinding: Media Pembinaan Hukum Nasional 1, no. 3, 2012.

Khaeruman, Badri. "Al-Qaradawi Dan Orientasi Pemikiran Hukum Islam Untuk Menjawab Tuntutan Perubahan Sosial." Wawasan: Jurnal Ilmiah Agama Dan Sosial Budaya 1, no. 2, 2016. https://doi.org/10.15575/jw.v1i2.740.

- - - . Hukum Islam Dalam Perubahan Sosial. Bandung: Pustaka Setia, 2010.

Kodir, Faqihuddin Abdul. "Metode Interpretasi Teks-Teks Agama Dalam Mazhab Salafi Saudi Mengenai Isu-Isu Gender." Holistik 13, no. 02, 2012.

KSA. “Vision 2030 Kingdom of Saudi Arabia," 2016.

Kurniawan, Nalom. "Hak Asasi Perempuan Dalam Perspektif Hukum Dan Agama." Jurnal Konstitusi 4, no. 1, 2011.

Mujihastuti, Nimas Ayu. "Analisis Perubahan Kebijakan Arab Saudi Tentang Peran Perempuan Di Ranah Publik: Studi Kasus Royal Decree No. M/85 Tahun 2017." Universitas Airlangga, 2019. https:/ / doi.org/10.1051/matecconf/201712107005.

"Muna AbuSulayman منى (@abusulayman) on Twitter." Accessed December 11, 2019. https:/ / twitter.com/abusulayman.

Murniasih, Gita, Diah Handayani, and Taufik Alamin. "Proses Domestifikasi Perempuan Dalam Budaya Arab (Analisis Framing Model Zhongdang Pan Dan Gerald M. Kosicki Dalam Film Wadjda)." Mediakita 2, no. 1, 2018.

Ni'mah, Zulfatun. "Fiqih Perubahan Untuk Perempuan (Upaya Menjawab Keusangan Dan Kekosongan Hukum Bagi Perempuan)." MUWAZAH 1, no. 1, 2009.

Rachmadie, Cammelianne Typhano, and Suryo Ediyono. "Reformasi Sistem Kebudayaan Di Arab Saudi Masa Pemerintahan Raja Abdullah (2005- 2015)." Millati: Journal of Islamic Studies and Humanities 2, no. 1, 2017. https:// doi.org/10.18326/millati.v2i1.

Rohman, Holilur. “Reinterpretasi Konsep Mahram Dalam Perjalanan Perempuan Pespektif Hermeneutika Fazlur Rahman." Al-Hukama 07, no. 02, 2017. 
Roji, Fatkhur. "Kebijakan Ruang Publik Perempuan: Agenda Politik Double Interest Saudi." International Journal Ihya' 'Ulum Al-Din 19, no. 2, 2017. https:/ / doi.org/10.21580/ihya.18.1.1740.

Rosida, Anis. "Wacana Modernisasi Dalam Tantangan Peradaban, Peran Perempuan Sebagai Tonggak Sejarah Arab Saudi." Palita: Journal of Social-Religion Research 3, no. 1, 2018. https://doi.org/10.24256/pal.v3i1.195.

"Saudi Arabia: Law on Passports Amended to Allow Women to Travel Abroad Without a Male Guardian | Global Legal Monitor." Accessed December 10, 2019. http://www.loc.gov/law/foreign-news/article/saudi-arabialaw-on-passports-amended-to-allow-women-to-travel-abroadwithout-a-male-guardian/.

"Saudi Arabia Extends New Rights to Women in Blow to Oppressive System - The New York Times." Accessed December 11, 2019. https://www.nytimes.com/2019/08/02/world/middleeast/sau di-arabia-guardianship.html.

Soekarba, Siti Rohmah. "Determinants of Patriarchy in the Middle East: Hope for the 2030 Vision in a New Saudi Arabia." In 2nd International Conference on Strategic and Global Studies (ICSGS 2018. Atlantis Press: Advances in Social Science, Education and Humanities Research, 2019.

Ulya, Atiyatul. "Konsep Mahram Jaminan Keamanan Atau Pengekangan Perempuan." Al-Fikr 17, no. 1, 2013.

Utami, Maulidah Tri. "Mahram Implications in Women's Travel." Jurnal Hunafa: Studia Islamika 16, no. 1, 2019. https:// doi.org/10.1017/CBO9781107415324.004.

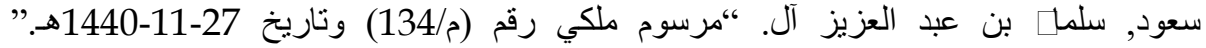
29/11/1440. https://perma.cc/9PHWEG7D. 